\title{
Pedagogias de Paulo Freire: educando para a cidadania com protagonismo na comunicação
}

Fabiana da Costa Pereira

Professora do Curso de Jornalismo na UFN. Doutora e mestre pela UFSM.

E-mail: rpfabianapereira@gmail.com

Ivete Fossá

Professora titular da UFSM, com estágio pós-doutoral junto ao Centro de Estudos da Argentina Rural da Universidade Nacional de Quilmes/Argentina, com bolsa Capes.

E-mail: fossa@terra.com.br

Resumo: Neste artigo, refletimos acerca das pedagogias propostas por Paulo Freire, na perspectiva da educação transformadora, que parte do contexto do educando para levá-lo ao ato do pensamento crítico que reflete sua realidade e o torna protagonista da transformação social, desenvolvendo sua cidadania. Para isso, a comunicação tem papel essencial, visto que retrata a realidade, através tanto da grande mídia quanto de outros meios que oportunizem o contato com diferentes pontos de vista. E é nessa perspectiva que identificamos a pedagogia da comunicação a partir do olhar de Mario Kaplún, que pensa a comunicação intrinsecamente relacionada com a educação proposta por Freire, em que a educação libertadora oportunizará um indivíduo consumidor e produtor de uma comunicação crítica no exercício pleno de cidadania.

Palavras-chave: Pedagogia do oprimido; pedagogia da autonomia; pedagogia da comunicação; educação para cidadania; comunicação transformadora.
Abstract: This article reflects on the pedagogies proposed by Paulo Freire, from the perspective of transformative education, which starts from the context of the student to lead him to the act of critical thinking that reflects his reality and makes him a protagonist of social transformation, developing his citizenship. Communication plays an essential role, since it portrays reality, whether through the mainstream media or even other means that provide opportunities for contact with different points of view. In this perspective we identify a pedagogy of communication from the perspective of Mario Kaplún, who thinks of communication as intrinsically related to the education proposed by Freire, in which liberating education will provide opportunities for an individual who consumes and produces a critical communication in the full exercise of citizenship.

Keywords: Pedagogy of the oppressed; pedagogy of autonomy; pedagogy of communication; citizenship education; transformative communication. 


\section{comunicação \& educação • Ano XXVI • número 2 • jul/dez 2021}

\section{CONSIDERAÇÕES INICIAIS}

A educação para a cidadania tem, na perspectiva que queremos abordar, as bases que foram trabalhadas por Paulo Freire na busca da educação transformadora dos indivíduos, que teriam alavancados seus status de meros figurantes ao de protagonistas de suas histórias, as quais estão inscritas na história dos seus bairros, região e país. Neste artigo, seguimos os passos bibliográficos de Paulo Freire ${ }^{1}$, lançando nosso olhar, num primeiro momento, para a temática da educação como prática libertadora, levando em consideração a sociedade que se configura a partir de uma alarmante desigualdade social, na qual é preciso intervir para que mudanças possam ocorrer. E essa intervenção, para o autor, só é possível através da educação ao alcance de todos, o que é reforçado por Mário Kaplún², que aproxima a prática educadora do processo de comunicação.

É necessário salientar, a partir da perspectiva atual - no ano de 2021, tendo deixado para trás 16 anos de governo de partido popular através de Luiz Inácio Lula da Silva (de 2003 a 2011) e Dilma Rousseff (de 2011 a agosto de 2016, considerando que a presidenta eleita sofreu processo de impeachment, o qual foi e será sempre amplamente questionado no país e ao redor do mundo como golpe) -, que, entre os períodos de escrita dos livros Educação como prática de liberdade, lançado no Brasil em 1967, e Educação e mudança, lançado no Brasil em 1979, existe uma grande distância temporal e de conquistas sociais. Podemos dizer que já esteve um pouco menor, porém sempre existente, o fosso social entre camadas da população, que, nos últimos anos, vem novamente se ampliando.

É nesse sentido que vamos nos apropriando dos pensamentos de Freire e atualizando às condições que hoje se apresentam, já que ainda possuímos as preocupações e desigualdades oriundas daqueles tempos, somente transportadas para outros patamares. Na sequência, as pedagogias é que são o nosso foco de atenção, por serem respostas ao fazer educativo voltado à população, na busca da transformação. Assim, a partir da Pedagogia do oprimido, lançado no Brasil em 1974 e Pedagogia da autonomia, lançado em 1996, elencamos as práticas libertadoras que servirão, na nossa perspectiva, como os alicerces para a educação para a cidadania.

Reforçando nosso olhar, abordamos a obra Uma pedagogia de la comunicación, de Kaplún, lançada na Espanha em 1998, que contribui para a perspectiva da relação da educação com a comunicação para o desenvolvimento de sujeitos que sejam produtores e consumidores de uma comunicação que abre espaço ao pensamento crítico e participativo no pleno exercício da cidadania. Desenvolvemos este estudo de natureza qualitativa através da pesquisa e análise bibliográfica. 


\section{PEDAGOGIA DO OPRIMIDO: UM OLHAR DA COLONIZAÇÃO AOS DIAS ATUAIS}

Caracterizar a população brasileira como "passiva" diante das injustiças sociais é jogar, de forma simplista, nas mãos do próprio povo a responsabilidade única pela sua trajetória. Para sair desse raciocínio, que mais justifica do que busca conhecer o caminho que nos trouxe aos dias atuais, é preciso um olhar atento e crítico à história do nosso país, passando pela colonização, ditaduras e processos democráticos (chamamos "processos" por entendermos que ainda não conseguimos atingir, em nenhum dos governos, uma gestão realmente democrática, justamente pela falta de maior participação da população). Apesar da tão reconhecida passividade brasileira, salientamos que, no período da ditadura civil-militar (1964-1985), tivemos um grande movimento de resistência, iniciado por estudantes e logo engrossado pelos sindicatos, movimentos campesinos, grupos católicos de movimentos de base popular, chegando a grupos de luta armada. Todos esses foram atores importantes, em momento de grande tensão social no país, na busca pela volta do sistema democrático de governo e pelo reconhecimento de direitos humanos e constitucionais, que estavam desconsiderados.

Do período de colonização, trazemos a herança da grande disparidade nas classes sociais, em que os donos de capital - no início, proprietários de terra e, depois, donos dos meios de produção - tinham o poder de mando e comando da massa de empregados, fossem indígenas, no início, e, depois, os negros escravizados, ou mesmo os brancos pobres, que trabalhavam para sobreviver. Sem vez nem voz, a maioria da população pobre ou escrava não tinha nenhuma possibilidade de escolha, sendo relegada a sobreviver sob condições sub-humanas. Mesmo com o fim da escravidão e a vinda dos imigrantes, a população, mais diversificada, manteve-se submissa a uma elite que coordenava seus modos de ser e fazer, por meio de uma doutrinação da força do poder econômico e político que definia quem sabia o que devia ser feito - os letrados e "bem" educados nas cortes europeias - e quem obedecia por não saber o que fazer - os "ignorantes" de estudo, analfabetos que só possuíam como moeda de troca, para sua sobrevivência, a força da mão de obra. Essa situação de submissão muito pouco mudou com o desenvolvimento, ao longo do tempo, de governos de base mais popular e democrática, e menos ainda nos períodos ditatoriais ou conservadores. Algumas conquistas são marcantes, como os direitos trabalhistas, iniciados no governo de Getúlio Vargas, que trouxeram condições mais dignas aos empregados. Porém, essas conquistas não alteraram a configuração social do país, que se apresentava cada vez mais numa disparidade de condições econômicas. Conforme Freire ${ }^{3}$ :

As tarefas de seu tempo não são captadas pelo homem simples, mas a ele apresentadas por uma 'elite' que as interpreta e lhes entrega em forma de receita, de prescrição a ser seguida. E, quando julga que se salva seguindo as prescrições,

3. FREIRE, Paulo. Educação como... Op. cit., p. 63. 


\section{comunicação \& educação • Ano XXVI • número 2 • jul/dez 2021}

afoga-se no anonimato nivelador da massificação, sem esperança e sem fé, domesticado e acomodado: já não é sujeito. Rebaixa-se a puro objeto. Coisifica-se.

Essa relação do homem como objeto não permite que ele identifique a situação de submissão em que se encontra, já que não sabe ter outra opção além da que lhe foi apresentada a vida toda, herdada do grupo familiar. Para Freire ${ }^{4}$, essa situação só poderá ser alterada a partir de um processo educativo da população que apresente condições para a formação de "postura de auto-reflexão e de reflexão sobre seu tempo e seu espaço. Auto-reflexão que as levará ao aprofundamento consequente de sua tomada de consciência e de que resultará sua inserção na História, não mais como espectadoras, mas como figurante e autoras". Dessa construção sai o homem sujeito que, ao se desacomodar do lugar onde se encontra, lança um outro olhar aos temas e tarefas que circulam ao seu redor, numa postura crítica ao status quo em que está situado. Sem chegar aqui, suas preocupações não saem das condições de sobrevivência. Ainda Freire ${ }^{5}$ :

Suas preocupações se cingem mais ao que há nele de vital, biologicamente falando. Falta-lhe teor de vida em plano mais histórico. É a consciência predominante ainda hoje, dos homens de zonas fortemente atrasadas do País. Esta forma de consciência representa um quase incompromisso entre o homem e sua existência. Por isso, adstringe-o a um plano de vida mais vegetativa. Circunscreve-o a áreas estreitas de interesses e preocupações. [...] Escapa ao homem intransitivamente consciente a apreensão de problemas que se situam além de sua esfera biologicamente vital. Daí implicar numa incapacidade de captação de grande número de questões que são suscitadas.

Justamente, é olhar de forma aprofundada as temáticas que perpassam a vida das comunidades que possibilita que os indivíduos se posicionem diante dos problemas. Mas essa tomada de consciência não se dá automaticamente, ao se apresentar à população, de forma narrada, sua história de vida ou mesmo um olhar crítico sobre determinado assunto. A essa prática Freire ${ }^{6}$ denomina "educação bancária", considerando que busca "depositar" no outro o conhecimento que, em princípio, do nosso ponto de vista, lhe falta. Para o autor, o homem aprende à medida que conhece, e quando conhece, se compromete com o fruto de seu aprendizado. "Quando o homem compreende sua realidade, pode levantar hipóteses sobre o desafio dessa realidade e procurar soluções. Assim, pode transformá-la e com seu trabalho, pode criar um mundo próprio: seu eu e suas circunstâncias"7. O autor entende ainda que não há possibilidade de aprendizado e de consciência quando se entrega aos indivíduos "prescrições

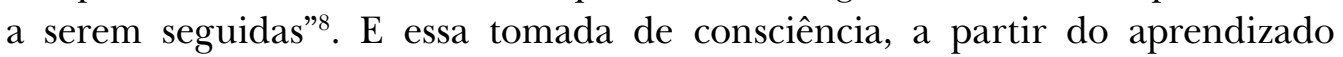
pela própria experiência, não é privilégio de alguns, mas é da prática de todo

4. Ibidem, p. 36

5. Ibidem, p. 58.

6. FREIRE, Paulo. Educação e... Op. cit., p. 21.

7. Ibidem, p. 16.

8. Ibidem, p. 102 homem e por isso mesmo deve ser estimulada, para que esses possam refletir sobre suas vivências.

Mas essa mudança de postura só tem condições de acontecer ao longo do tempo, num trabalho educativo dialógico crítico. Só que esse é um grande passo. No Brasil passado, urgente se fazia vencer o analfabetismo para conseguir avançar no aprendizado da participação social que traria condições à 
tomada de decisão na vida política do país, ganhando espaços de participação - desde a presença na escola dos filhos até a participação nos sindicatos, nas agremiações, nos clubes, nas igrejas, nas associações de bairro, nos conselhos etc. Em 2019, o analfabetismo se resumia a $6,6 \%$ da população ${ }^{9}$, porém ainda é importante avançar no aprendizado da participação social. Muitos espaços se criaram, como os Conselhos Municipais na área de saúde, educação e assistência social, sem falar no voto direto que, desde as eleições de 1989, é realidade no país. Porém, as participações não se configuraram para além dos momentos de pleito, faltando ainda a cultura do acompanhamento como processo de cobrança de prestação de contas aos representantes eleitos.

A redemocratização do país, há pouco mais de 30 anos, trouxe novas perspectivas à população, pois devolveu o direito da escolha direta do presidente, após 21 anos de ditadura, que impingiu ampla censura à imprensa e à população, em relação a seu direito de manifestação e participação ativa na vida política brasileira. Desse período ditatorial, herdamos a presença marcante da propaganda ideológica, difundida em diferentes espaços, como na programação e na cobertura da mídia, na doutrinação das escolas, principalmente as públicas, nos discursos dos agentes de Estado e dentro dos órgãos de governo - nos diferentes âmbitos, municipal, estadual e federal. Essa força ideológica procurou sempre eliminar enfrentamentos com pensamentos antagônicos, através do silenciamento da população, que era vista como uma massa que deveria ser sugestionada a se adaptar ao que estava posto. Nesse sentido, o forte vínculo com a cultura de massa norte-americana, através da difusão de programas de tevê e do cinema, propiciou a desvinculação de parcela da população das problemáticas locais, pois o entretenimento ganhava boa parte dos horários da grade de programação das tevês comerciais e os noticiários focavam nas questões internacionais. Essas condições levaram, de forma proposital, a sociedade a uma alienação político-social que não permitiu ao indivíduo uma consciência do seu próprio modo de existir. Conforme Freire $^{10}$, "o ser alienado não olha para a realidade com critério pessoal, mas com olhos alheios. Para isso vive uma realidade imaginária e não a sua própria realidade objetiva”. Condições favoráveis para reforçar o domínio político ideológico da elite brasileira no momento.

Porém, a volta da democracia devolveu a força aos espaços de resistência a essa doutrinação ideológica da elite. Os sindicatos, principalmente, fomentaram manifestações de descontentamento às condições de vida da população brasileira desde os assuntos mais primordiais, como saúde, educação e cultura. As reivindicações ganharam proporções nacionais e algumas conquistas foram alcançadas. Por outro lado, foi momento, também, de grande difusão das entidades assistenciais, as quais vinham em "auxílio da população", ocupando o espaço do Estado no enfrentamento imediato de problemas de ordem mais prática, sem, no entanto, se organizarem para mudar o status quo através do desenvolvimento econômico e social ou da educação, num trabalho conjunto em busca de soluções aos problemas da população. Apareciam para acomodar a situação ora apresentada pela população, implantando suas respostas. Conforme
9. TOKARNIA, Mariana. Analfabetismo cai, mas Brasil ainda tem 11 milhões sem ler e escrever. Agência Brasil, Rio de Janeiro, 15 jul. 2020. Disponível em: https://agenciabrasil. ebc.com.br/educacao/ noticia/2020-07/taxa-cai-levemente-mas-brasil-ainda-tem-11-milhoes-de-analfabetos\#: :text=A\%20 taxa\%20de\%20analfabetismo\%20no,ainda\%2011\%20 milh\%C3\%B5es\%20de\%20 analfabetos. Acesso em: 16 nov. 2021.

10. FREIRE, Paulo. Educação e... Op. cit., p. 19. 
Freire $^{11}$, as entidades assistenciais "não prestam serviços, atuam paternalisticamente, o que é uma forma de colonialismo". O desenvolvimento das entidades assistenciais prestou seu papel de apaziguador da situação de instabilidade presente, principalmente nos primeiros anos de governo civil.

O grande perigo do assistencialismo está na violência do seu antidiálogo, que, impondo ao homem mutismo e passividade, não lhe oferece condições especiais para o desenvolvimento ou a 'abertura' de sua consciência que nas democracias autênticas há de ser cada vez mais crítica. Sem essa consciência cada vez mais crítica não será possível ao homem brasileiro integrar-se à sua sociedade em transição, intensamente cambiante e contraditória. Daí as relações do assistencialismo com a massificação, de que é a um tempo efeito e causa. O que importa, realmente, ao ajudar-se o homem é ajudá-lo a ajudar-se (E aos povos também). É fazê-lo agente de sua própria recuperação. É, repitamos, pô-lo numa postura conscientemente crítica diante de seus problemas. ${ }^{12}$

Nessa perspectiva, e tendo o processo democrático se fortalecido ao longo do tempo através das eleições diretas, é que entendemos que a população, aos poucos, deveria apropriar-se de formas mais concretas de participação na vida política brasileira. Mas, por enquanto, essa participação se dá de forma incipiente e representativa, por meio do pleito que acontece a cada dois anos, o que não coloca a população realmente à frente da tomada de decisões importantes que refletem no seu dia a dia. Eleger representantes sem acompanhá-los para que cumpram suas promessas de campanha - as quais são as bases de arrecadação dos votos - é continuar relegando a terceiros as responsabilidades na busca das transformações sociais tão necessárias para grande parcela da população. Para mudar esse comportamento, é preciso tomar consciência de que a realidade é construída e que cada indivíduo tem uma parcela de responsabilidade sobre o que acontece no seu entorno. Para que ocorra essa tomada de consciência é que se faz necessária uma educação transformadora.

A consciência crítica, conforme Freire $^{13}$, exige uma análise aprofundada dos problemas, procurando a causalidade dos fatos. Não se exime de responsabilidades e autoridade, pelo contrário, repele a quietude, já que está sempre investigando, verificando e testando as descobertas, mas sempre aberta às revisões de posicionamento. Até porque identifica quando não tem meios para melhor análise e busca se desvencilhar de preconceitos. "Face ao novo, não repele o velho por ser velho, nem aceita o novo por ser novo, mas aceita-os na medida em que são válidos" ${ }^{\prime 4}$. Por isso, o homem com consciência crítica não pode ser neutro diante dos acontecimentos do mundo, muito menos do que lhe acontece no dia a dia. "No momento em que os indivíduos, atuando e refletindo, são capazes de perceber o condicionamento de sua percepção pela estrutura em que se encontra, sua percepção muda, embora isto não signifique, ainda, mudança da estrutura"15. A percepção dessa realidade, enquanto constrói o homem, também é construída por ele, o tirando de um posicionamento fatalista, no qual não havia espaço para mudança, considerando que tudo já estava definido pela própria realidade. "O fatalismo diante da realidade, característico 
da percepção distorcida, cede lugar à esperança. Uma esperança crítica que move os homens para a transformação"16.

E é justamente a educação transformadora, dialógica, que pode oportunizar a tomada de consciência crítica do indivíduo, ao instigá-lo ao reconhecimento de sua inserção no contexto em que vive e do poder que tem de transformá-lo. Reconhecimento esse que não pode ser dado pronto pela elite dominante, visto que essa nunca lhe alcançará os instrumentos para libertar-se justamente do domínio cultural e econômico que lhe impôs. Para Freire "a pedagogia do oprimido, que não pode ser elaborada pelos opressores, é um dos instrumentos para esta descoberta crítica"17, sendo diferente "educar para" de "educar com", através da tomada de consciência pela vivência.

A pedagogia do oprimido propõe a problematização da realidade para o educando, desafiando-o a buscar soluções que considerem sua vivência e realidade como base para interpretação dos fatos, para que as respostas não fiquem tão longe do seu alcance nem pareçam não lhes dizer respeito ou que já não podem fazer nada para mudar o status estabelecido. Ao educando é preciso mostrar as interconexões que as situações trazem, ampliando o contexto do local para o regional e nacional para que não sejam pensados como fatos isolados. Essa imersão no contexto oportuniza a emersão da consciência crítica desalienante. "Através dela, que provoca novas compreensões de novos desafios, que vão surgindo no processo da resposta, se vão reconhecendo, mais e mais, como compromisso. Assim é que se dá, o reconhecimento que engaja"18.

Ainda, como educação transformadora, a pedagogia do oprimido tem na essência o diálogo como prática libertadora, já que a palavra leva à reflexão e à concretude das ações do indivíduo. Conforme o autor, se fala do que faz, o homem tem uma palavra autêntica, validada pelas práxis; se não, a palavra se transforma em verbalismo e, por isso mesmo, alienante e alienada. Ao mesmo tempo, se somente age, sem refletir na sua prática, partimos para o ativismo, que, da mesma forma, impossibilita o diálogo, sem o qual caímos na educação bancária, em que os que são considerados os sábios doam conhecimento aos que estão prontos para receber, considerando que são julgados e julgam nada saber. E esse saber, que vem da fala narrada e transmitida, não oportuniza conhecimento, pois está desvinculado da experiência e, por isso mesmo, não causa transformação. No máximo, gera conformismo ao indivíduo, dando-lhe argumentos para adaptar-se à situação na qual se encontra. "A existência, porque humana, não pode ser muda, silenciosa, nem tampouco pode nutrir-se de falsas palavras, mas de palavras verdadeiras, com que os homens transformam o mundo. Existir, humanamente, é pronunciar o mundo, é modifica-lo"19. Utilizar-se da palavra é imprescindível para o homem enxergar-se como participante do mundo. É o diálogo que dá oportunidade de fala a todos. Apropriar-se da palavra do outro não é lhe dar poder de fala, mas justamente impedir a autonomia de sua existência e, com isso, seu poder de transformação da realidade.

Essa perspectiva deixa clara a necessidade de uma sociedade democrática ter diferentes indivíduos ocupando os espaços políticos - e políticos justamente

16. Ibidem, p. 27.

17. FREIRE, Paulo. Pedagogia do..., Op. cit., p. 43.

18. Ibidem, p. 98.

19. Ibidem, p. 108. 
por serem espaços de disputas - para que tragam a voz de suas comunidades, exprimindo seus anseios e necessidades, e para que se enxerguem nesse espaço de transformação social. Conforme Freire, "não é no silencio que os homens se fazem, mas na palavra, no trabalho, na ação-reflexão" ${ }^{20}$, pois, ao expor sua realidade, o homem é instigado à problematizá-la. E é esse, com certeza, o receio da elite dominante, que não oportuniza a fala dos dominados, muito pelo contrário, se utiliza dos aparatos de comunicação (geralmente organizados em grandes grupos econômicos) para entregar a fala pronta, sem espaço para problematizações. Diferentemente do que propõe o autor, fazer uso da palavra, ainda no Brasil atual, é privilégio de poucos, mesmo sendo direito de todos. E é por isso que, para a maior parcela da população, o direito de fala é fato ainda a ser conquistado.

Esta é a razão por que não é possível o diálogo entre os que querem a pronúncia do mundo e os que não a querem; entre os que negam aos demais o direito de dizer a palavra e os que se acham negados deste direito. É preciso primeiro que, os que assim se encontram negados no direito primordial de dizer a palavra, reconquistem esse direito, proibindo que este assalto desumanizante continue. Se é dizendo a palavra com que, 'pronunciando' o mundo, os homens o transformam, o diálogo se impõe como caminho pelo qual os homens ganham significação enquanto homens ${ }^{21}$.

O pensar não existe desvinculado da realidade e, por isso, a palavra ao mesmo tempo que reforça o pensar, vincula o homem à sua realidade, pois toda palavra está ligada a uma realidade concreta, da qual partiu para existir no mundo. E para o homem ter consciência de onde saiu a palavra e em que realidade ela está vinculada, é preciso que tenha noção de si e do espaço que ocupa no mundo, assim como é preciso que perceba que há vários outros indivíduos ocupando esse mesmo espaço, com outras realidades também concretas, e que essas, em boa parte do tempo, estão em disputa de espaço e poder. "O que temos de fazer, na verdade, é propor ao povo, através de certas contradições básicas, sua situação existencial, concreta, presente, como problema que, por sua vez, o desafia e, assim, lhe exige resposta, não só no nível intelectual, mas no nível da ação" ${ }^{2}$. Para além do discurso, a palavra deve levar à ação concreta se o homem quiser realmente transformar sua realidade na busca de melhores condições de vida. Como transformadores da realidade, os homens criam objetos e situações, fatos e instituições, suas ideias e concepções.

20. Ibidem, p. 108 21. Ibidem, p. 109. 22. Ibidem, p. 120 23. Ibidem, p. 120

\section{PEDAGOGIA DA AUTONOMIA: NA INFORMAÇÃO, A CONSTRUÇÃO DO PENSAMENTO CRÍTICO}

Pela pedagogia do oprimido, Freire ${ }^{23}$ propõe como método educativo que as temáticas a serem abordadas saiam da realidade do educando para que sejam situações conhecidas a serem reconhecidas dentro de um contexto que saliente, comparando realidades, as limitações e novas 
possibilidades, oportunizando a percepção da realidade distorcida que era percebida. Mas é preciso que se utilize de códigos simples, que possam ser decodificados e analisados de forma plural, além de sempre partir de casos singulares para se chegar na situação geral. Ainda, o autor instiga o uso da produção da mídia como recurso didático, através da comparação de diferentes posicionamentos diante de um mesmo acontecimento, por meio da leitura de editoriais, artigos, livros etc. Faz-se necessária a busca de diferentes pontos de vista para o desenvolvimento de um pensamento crítico, para que o consumo de informações não ocorra de forma prescrita, como fazem os meios de comunicação, mas com um olhar liberto, que tenha espaço para questionamentos e contraversões. Dar autonomia ao indivíduo requer dar-lhe condições de análise do contexto, possibilitando o conhecimento das diferentes perspectivas pelas quais o fato pode ser interpretado, para que decida, por conta própria, a versão que melhor represente seu pensamento. Ao mesmo tempo, impõe-se que o indivíduo atente para o fato de que seu posicionamento também será um ponto de vista, entre tantos possíveis e, assim, passível de equívoco e reavaliação, o que não é um problema, conforme Freire ${ }^{24}$ : "o erro na verdade não é ter um certo ponto de vista, mas absolutizá-lo e desconhecer que, mesmo do acerto de seu ponto de vista, é possível que a razão ética nem sempre esteja com ele".

É na pedagogia da autonomia que encontramos esse outro passo para a educação transformadora que, mais do que colocar o indivíduo no papel de construtor da realidade, o faça se reconhecer como sujeito único, diferente dos demais, e reconheça o outro também como sujeito, com o qual interage justamente para construir esse mundo onde convivem. Essa autonomia de reconhecimento de si e do outro impõe a necessidade de uma presença ética e responsável no mundo. Ao mesmo tempo que o indivíduo toma para si, na sua autonomia, a avaliação, opção e decisão das coisas no mundo, também traz para si a impossibilidade de ausentar-se da construção dessa história de mundo, por mais que evoque a determinação genética, cultural ou de classes. "Significa reconhecer que somos seres condicionados mas não determinados. Reconhecer que a história é tempo de possibilidade e não de determinismo, que o futuro, permita-se-me reiterar, é problemático e não inexorável”"25. A pedagogia da autonomia propõe que o indivíduo desenvolva condições para buscar a transformação, enfrentando o fatalismo naturalizado em seu reconhecimento da realidade, presente na ideologia dominante que se perpetua na mídia e nos diferentes espaços de poder, inclusive nos discursos oficiais de governos.

A ideologia fatalista, imobilizante, que anima o discurso neoliberal anda solta no mundo. Com ares de pós-modernidade, insiste em convencer-nos de que nada podemos contra a realidade social que, de histórica e cultural, passa a ser ou a virar 'quase natural'. Frases como 'a realidade é assim mesmo, que podemos fazer?' ou 'o desemprego no mundo é uma fatalidade do fim do século' expressam bem o fatalismo desta ideologia e sua indiscutível vontade imobilizadora. Do ponto de vista de tal ideologia, só há uma saída para a prática educativa: adaptar o educando a esta realidade que não pode ser mudada. ${ }^{26}$

24. FREIRE, Paulo. Pedagogia da... Op. cit., p. 16.

25. Ibidem, p. 20, grifo do autor.

26. Ibidem, p. 21, grifo do autor. 


\section{comunicação \& educação • Ano XXVI • número 2 • jul/dez 2021}

É justamente para combater essa ocultação da verdade dos fatos que, sob determinado ponto de vista, se faz mais nos discursos do que na busca de dados concretos e analíticos, que a pedagogia da autonomia propõe que possamos estar em dúvida constante, através da curiosidade, comparação e constatação, num eterno aprender, para superar esses processos condicionantes. Para isso, quando constatamos o fato, não podemos nos calar e nos manter na acomodação, pois o silêncio nos faz negadores da nossa própria autonomia, e o discurso do silêncio é o passo para a adaptação e aceitação do fato como sina, o que nos leva à impotência. A autonomia não nos dá o direito de nos eximirmos da responsabilidade em relação aos acontecimentos do mundo. Muito mais trabalhoso é intervir na realidade do que nos adaptarmos a ela, porém, ao tomarmos consciência do papel que temos, como indivíduos históricos e culturais, não podemos estar no mundo de forma neutra. "Que é mesmo a minha neutralidade se não a maneira cômoda, talvez, mas hipócrita, de esconder minha opção ou meu medo de acusar a injustiça? 'Lavar as mãos' em face da opressão é reforçar o poder do opressor, é optar por ele" ${ }^{27}$.

A autonomia só se realiza na prática do exercício da tomada de consciência de si, do outro e do mundo, através das necessidades de tomada de decisões em diferentes contextos, pois "é decidindo que se aprende a decidir" 28 . Da mesma forma, só podemos aprender sobre o outro se o escutamos e só assim também conseguiremos falar com ele. E falar ao outro não quer dizer impor-lhe a nossa opinião, pois embora possamos discordar e mostrar nossa opinião e posição, podemos fazer isso considerando-o como sujeito da escuta, também autônomo, e não como mero objeto do nosso discurso. E, para isso, devemos considerar que se temos o que dizer, principalmente se discordamos do outro, também temos o que escutar, e devemos dar a ele a possibilidade de manifestação, para que também exista pela palavra e se posicione diante da realidade que compartilhamos. "Quem tem o que dizer tem igualmente o direito e o dever de dizê-lo. É preciso, porém, que quem tem o que dizer saiba, sem sombra de dúvida, não ser o único ou a única a ter o que dizer" ${ }^{29}$. Ainda, o autor salienta que justamente por não ter espaço de escuta, por não se abrir para a diversidade de pontos de vistas, é que os discursos vão ficando retóricos e repetitivos, pois nada acrescentam ao que já se sabe. "Por isso é que, acrescento, quem tem o que dizer deve assumir o dever de motivar, de desafiar quem escuta, no sentido de que, quem escuta diga, fale, responda"30.

Dentro desse contexto, entendemos que a pedagogia do oprimido e a pedagogia da autonomia propõem levar os educadores, sejam professores, pais, chefes, governantes e, na nossa concepção, os próprios veículos de comunicação a

27. Ibidem, p. 109, grifo do autor.

28. Ibidem, p. 104.

29 Ibidem, p. 114.

30. Ibidem, p. 114, grifo do autor. repensarem suas práticas educadoras, questionando mesmo o papel da educação.

Uma das mais sistemáticas formas de intervenção na vida do indivíduo, já que está presente em todas as etapas do seu desenvolvimento, a educação trabalha no sentido tanto de ser a mediadora para justificar o status quo existente, reproduzindo a ideologia dominante, como também exerce papel contestatório, procurando desmascarar as contradições da realidade, vendidas 
como normalidades para a população e, por isso, aparentemente imutáveis. Indiferentemente do posicionamento, o que é preciso deixar claro, conforme a perspectiva do próprio autor, é que a educação em qualquer dos casos é ideológica por si só, visto que, de todas as formas, não é neutra. E justamente por isso, quanto mais dialógica, mais será libertadora. O processo para "despertar a minha capacidade de pensar certo, de ver com acuidade, de ouvir com respeito, por isso de forma exigente, é me deixar exposto às diferenças, é recusar posições dogmáticas, em que me admita como proprietário da verdade" ${ }^{31}$. Nesse sentido, é importante pensar o papel da comunicação, que é responsável pelo processo de difusão de informações.

\section{A PEDAGOGIA DA COMUNICAÇÃO: ÊNFASE NO CONTEÚDO, NOS EFEITOS OU NOS PROCESSOS}

A prática educadora adotada em um espaço, seja comunidade ou país, vai refletir no comportamento do corpo social, como afirma Kaplún, identificando que "a cada tipo de educação corresponde uma determinada concepção e uma determinada prática de comunicação" ${ }^{32}$. Inspirado nos modelos de Díaz Bordenave, pesquisador e intelectual paraguaio considerado um dos pioneiros no estudo de educomunicação, o autor aborda as três possibilidades de práticas comunicativas, as quais também refletem aquelas abordadas por Freire: a educação que enfatiza o conteúdo; a educação que enfatiza os efeitos e, por último, a educação enfatiza o processo.

Nas duas primeiras, o educando é um objeto passivo do processo de educação; somente no terceiro modelo ele toma o lugar de sujeito nesse processo. Para Kaplún ${ }^{33}$, a primeira, que valoriza o conteúdo, é a educação bancária que Freire aborda, a educação tradicional; a segunda, que valoriza os efeitos, é a chamada engenharia do comportamento, que tem por objetivo moldar o comportamento das pessoas; e a terceira, que tem o olhar voltado ao processo, é a que realmente se interessa pelo desenvolvimento do educando; baseada no diálogo, busca a consciência social do indivíduo, e é chamada por Freire de educação libertadora. A cada uma dessas práticas, Kaplún vincula um modelo de comunicação e comportamento do público diante dessa comunicação.

O autor entende que o modelo bancário de educação será refletido por uma comunicação bancária, na qual o emissor, que é detentor do conhecimento e da informação, envia uma mensagem ao receptor passivo. Esse processo é de uma via, não propõe diálogo, é um monólogo. Conforme Kaplún ${ }^{34}$, não são somente os grandes veículos os usuários desse tipo de comunicação, considerando que, se ao organizarmos informativos, vídeos, obras de teatro, não deixarmos espaço para a interação com o público, continuamos mantendo a comunicação autoritária no nosso próprio meio, perpetuando a comunicação bancária.

A programação educativa das tevês, a partir do uso das tecnologias para produção de conteúdo educativo, em geral, não muda essa concepção, visto que

31. Ibidem, p. 131.

32. KAPLÚN, Mario. Una pedagogía..., Op. cit., p. 15, tradução nossa.

33. Ibidem.

34. Ibidem 
não deixa espaço de reflexão e questionamento, mas entrega o áudio, o vídeo, o conteúdo pronto, formatado, já idealizado para ser consumido pelo receptor. "Em síntese todos os que fazemos comunicação educativa deveríamos perguntar: Lançamos afirmações ou criamos condições para uma reflexão pessoal? Nossos meios monologam ou dialogam?" 35 .

O segundo modelo de educação, que tem ênfase no comportamento, avança um passo no processo ao se preocupar com o resultado, porém, para o autor, é tão autoritário quanto o outro ,e por desenvolver técnicas que afetam o comportamento, pode ser considerado o modelo da educação manipuladora. Ganhou espaço na América Latina como a salvação para o subdesenvolvimento dos países, que precisavam aprender as técnicas dos países desenvolvidos para chegar ao "progresso". O objetivo não era apenas passar a mensagem, mas convencer de que esta era a melhor alternativa e para isso a psicologia comportamental foi a área aliada, estudando métodos de persuasão.

A educação se dava no modelo estímulo resposta, criando outros hábitos no indivíduo. Para lidar com a resistência às mudanças, a orientação era o descaso, não havia disputa de ideias, simplesmente outras opções não eram consideradas; ignoradas, passavam a não existir. Mata-se aí a criatividade, a inovação, o interesse. Esse modelo repercutiu grandemente no campo da comunicação, pois o acompanhamento no feedback do comportamento do público orienta o caminho que a empresa pode tomar, o interesse do patrocinador, valendo tanto para anúncios publicitários quanto para telejornais, noticiários e outros programas. A reação da audiência chega a interferir no enredo da novela. Mas, para Kaplún ${ }^{36}$, não se limita a esses e questiona os comunicadores: "em que medida, consciente ou inconscientemente, reproduzimos em nossos atos de comunicação o tipo de pedagogia que põe ênfase nos efeitos?" 37 . Fazemos isso quando nos preocupamos mais com os efeitos do que com o processo, quando temos foco em desenvolver campanhas e mais campanhas sem buscar a participação efetiva do público, sem dar espaço para questionamentos.

O terceiro modelo, oriundo da educação libertadora e transformadora concebida por Paulo Freire, tem base na reflexão para a ação e foco na educação como processo contínuo, que não se encerra e que tem como protagonista o educador e o educando. Conforme Kaplún ${ }^{38}$, "o que o sujeito educando necessita não são só dados, informações, mas instrumentos para pensar, para inter-relacionar um fato com outro, tirar conclusões e consequências, para construir uma explicação global, uma cosmovisão coerente".

O modelo propõe a participação ativa do sujeito e o prepara para a

35. Ibidem, p. 25, tradução nossa.

36. Ibidem

37. Ibidem, p. 40.

38. Ibidem, p. 46, tradução nossa. participação na sociedade. É desenvolvido em grupo, estimulando a troca, a reflexão, o entendimento do conflito como aprendizagem. Mas o autor chama a atenção para o problema de um radicalismo nessa prática, em que o grupo poderia se fechar para contribuições externas, valorizando somente o que já sabe, o que Freire também salientou, ao lembrar que o indivíduo não deve se entender como dono da verdade. 
Nesse caso, é importante perceber que, quanto mais informações um grupo acessar, mais poderá avançar no seu desenvolvimento. O que é imprescindível é que essas informações venham acompanhadas de questionamentos para a reflexão e não sejam dadas como inquestionáveis. A comunicação que se estabelece a partir desse terceiro modelo de educação é dialógica e participativa, e deve dar ao indivíduo o espaço de ser emissor e receptor de informações.

Mas como estabelecer essa relação entre veículos e público? Que espaço é esse que precisa ser ocupado pelo indivíduo para que a comunicação também seja libertadora? Para o autor, é a comunicação que se estabelece com base popular, cuja fonte de informação é a própria comunidade, que se sente convidada a participar e a exercer sua cidadania. A construção da notícia se dá de forma conjunta, e cada um é livre para contribuir, por meio de sugestão, relato, informação, problemas e testemunhos. São temas locais que são conectados aos temas nacionais e internacionais e trazem a noção de pertencimento à comunidade dentro da realidade.

São grupos com diferentes interesses, como os religiosos, sindicatos, jovens, mulheres, esportistas, artistas, participando conjuntamente da produção de um veículo de comunicação, seja um jornal comunitário ou mesmo um canal de rádio ou tevê. Para validar essa construção conjunta, Kaplún ${ }^{39}$ propõe uma pesquisa que ouça a avaliação da população no que tem de positivo e negativo, buscando a melhoria contínua e uma aproximação maior a cada edição. Para que funcione, essa comunicação dialógica precisa partir de um grupo que tome a dianteira e estabeleça esse processo desde o início. No nosso entendimento, essa possibilidade se amplia quando há autonomia, quando o indivíduo entende o lugar que ocupa e que o direito à comunicação também é cidadania. Inter-relação que exige que as pedagogias (do oprimido, da autonomia e da comunicação) sejam desenvolvidas em conjunto.

\section{CONSIDERAÇÕES FINAIS}

Educação e comunicação estão intrinsicamente ligadas, como já posto pelos autores Paulo Freire e Mário Kaplún, visto que o modelo de educação determina a forma como a comunicação será estabelecida. Se educado para aprender, na educação bancária, o sujeito entenderá a comunicação como processo de passividade, de onde recebe a informação sem ter outra reação. Se educado para agir, no modelo manipulador, entenderá a comunicação como estímulo para uma resposta, que não se dá de forma individual, mas dentro do esperado no comportamento coletivo, sendo estimulado a seguir a massa, pois, se reagir de forma diferente, será ignorado, ficará fora do "público" selecionado. Mas, se educado para pensar, no modelo da autonomia, o indivíduo reconhece o seu lugar no processo comunicativo como produtor e receptor da mensagem, já que, ao mesmo tempo que se abre para múltiplas fontes de informação, também 
entende que é de sua responsabilidade refletir e construir um pensamento próprio, tendo por base suas experiências e o diálogo com o grupo.

A educação transformadora possibilita a tomada de consciência do indivíduo como construtor da realidade em que se encontra inserido, e que encontra na autonomia o caminho para o reconhecimento de si e do outro como seres repletos de direitos e deveres - e que por isso mesmo devem agir com responsabilidade e ética, mas sem se eximirem da necessidade de interferência na situação dada - é pode levar o indivíduo ao desenvolvimento da cidadania e autonomia para receber e produzir comunicação. Cidadania essa que deve lhe permitir ser protagonista nas tomadas de decisão do que diga respeito a questões que afetem sua existência.

\section{REFERÊNCIAS BIBLIOGRÁFICAS}

FREIRE, Paulo. Educação como prática de liberdade. Rio de Janeiro: Paz e Terra, 1967.

FREIRE, Paulo. Educação e mudança. Rio de Janeiro: Paz e Terra, 1979.

FREIRE, Paulo. Pedagogia da autonomia: saberes necessários à prática educativa. São Paulo: Paz e Terra, 2011.

FREIRE, Paulo. Pedagogia do oprimido. 59. ed. Rio de Janeiro: Paz e Terra, 2015.

KAPLÚN, Mario. Una pedagogia de la comunicación (el comunicador popular). La Habana: Caminos, 2002.

TOKARNIA, Mariana. Analfabetismo cai, mas Brasil ainda tem 11 milhões sem ler e escrever. Agência Brasil, Rio de Janeiro, 15 jul. 2020. Disponível em: https://agenciabrasil.ebc.com.br/educacao/noticia/2020-07/taxa-cailevemente-mas-brasil-ainda-tem-11-milhoes-de-analfabetos\#: :text=A\% 20 taxa $\%$ 20de $\%$ 20analfabetismo \% 20no,ainda $\% 2011 \% 20$ milh $\%$ C3\%B5es $\% 20$ de\%20analfabetos. Acesso em: 16 nov. 2021. 